\title{
Cultivar, Growing Media, and Nutrient Source Influence Strawberry Yield in a Vertical, Hydroponic, High Tunnel System
}

\author{
Samuel E. Wortman ${ }^{1,4}$, Michael S. Douglass ${ }^{1}$, \\ and Jeffrey D. Kindhart ${ }^{2,3}$
}

AdDitionAl INDEX wORDs. controlled-environment agriculture, vertical farming, organic hydroponics, local foods

SUMMARY. Demand for local food, including strawberries (Fragaria $\times$ ananassa), is increasing throughout the United States. Strawberry production in the midwestern United States can be challenging due to the relatively short growing season and pests. However, vertical, hydroponic, high tunnel production systems could extend the growing season, minimize pest incidence, and maximize strawberry yield and profitability. The objectives of this study were to 1 ) identify the best cultivars and growing media for vertical, hydroponic, high tunnel production of strawberries in the midwestern United States and to 2) assess potential strategies for replacing synthetic fertilizer with organic nutrient sources in hydroponic strawberry production. To accomplish these objectives, three experiments were conducted across 2 years and two locations in Illinois to compare 11 strawberry cultivars, three soilless media mixtures, and three nutrient sources. Strawberry yield was greatest when grown in perlite mixed with coco coir or vermiculite and fertilized with a synthetic nutrient source. Yield was reduced by up to $15 \%$ when fertilized with a bio-based, liquid nutrient source and vermicompost mixed with soilless media. Strawberry yield among cultivars varied by year and location, but Florida Radiance, Monterey, Evie 2, Portola, and Seascape were among the highest-yielding cultivars in at least one site-year. Results contribute to the development of best management practices for vertical, hydroponic, high tunnel strawberry production in the midwestern United States, but further research is needed to understand nutrient dynamics and crop physiological response among levels within vertical, hydroponic towers.

$\mathrm{D}$ emand for local fruits and vegetables is growing steadily in the United States, and many consumers are willing to pay a premium for local food (Feldmann and Hamm, 2015). Unfortunately, local farmers are struggling to meet this growing demand

This project was supported by the Specialty Crop Block Grant Program at the U.S. Department of Agriculture through grant 12-25-B-1668 as administered by the Illinois Department of Agriculture.

We acknowledge co-author Jeff Kindhart, who passed away during the preparation of this manuscript. Jeff was a passionate horticultural researcher and educator dedicated to improving the lives of Illinois growers. Jeff initiated this project in 2012 at the Dixon Springs Agricultural Center and we began collaborating with him in 2013. We also thank Julie Zakes for her excellent work in managing trials and collecting data at Dixon Springs.

Its contents are solely the responsibility of the authors and do not necessarily represent the official views of the U.S. Department of Agriculture or the Illinois Department of Agriculture.

${ }^{1}$ Department of Crop Sciences, University of Illinois at Urbana-Champaign, Plant Sciences Laboratory, 1201 South Dorner Drive, Urbana, IL 61801

${ }^{2}$ Dixon Springs Agricultural Center, Department of Crop Sciences, University of Illinois at UrbanaChampaign, 354 State Highway 145 North, Simpson, IL 62985

${ }^{3}$ Deceased 8 Feb. 2016.

${ }^{4}$ Corresponding author. E-mail: swortman@illinois.edu. due to gaps in technical knowledge about specialty crop production systems that are new or potentially unique to a given agroecoregion. Given the smallscale and adverse climatic conditions of midwestern United States specialty crop farms, novel production systems are often needed to make local fruit and vegetable production feasible.

Strawberries, the fifth most popular fresh fruit in the United States [U.S. Department of Agriculture (USDA), 2012], typically are produced in California, but open-field strawberry production systems used in California are not ideal for the midwestern United States. Two major challenges of open-field strawberry production in the midwestern United States are pest management and the relatively short growing season. However, both of these challenges can be at least partially addressed by growing strawberries in a hydroponic system within high tunnels. Hydroponic production, through the use of nutrient solution or soilless substrates as growing media, eliminates weed management and soil pathogen concerns that typically plague strawberry (LaMondia et al., 2002). High tunnels extend the growing season in the midwestern United States allowing farmers to achieve earlier and more abundant strawberry yields (Knewtson et al., 2010). Vertical, hydroponic production systems used within high tunnels may help maximize the productivity and profitability of this valuable growing space (Karakoudas et al., 1998). While promising, vertical, hydroponic strawberry production in high tunnels combines two relatively new production systems; thus, growers have many practical management questions about the best cultivars and cultural practices before adopting this new system.

Many strawberry cultivars are available to farmers, but the majority of these cultivars were developed under soil-based field conditions in traditional strawberry production regions (e.g., California and Florida). Anagnostou and Vasilakakis (1995) demonstrated significant variability in yield and quality between strawberry cultivars grown in a vertical, hydroponic system, yet there are few published reports comparing modern strawberry cultivars in hydroponic culture (Miranda et al., 2014). Moreover, when hydroponic systems are used in high tunnels, cultivar performance will be further influenced by local climatic conditions and the unique microclimatic properties of high tunnel environments (Wien, 2009). Thus, studies and cultivar recommendations are needed for individual agroecoregions

\begin{tabular}{llll}
\hline $\begin{array}{l}\text { Units } \\
\text { To convert U.S. to SI, } \\
\text { multiply by }\end{array}$ & U.S. unit & SI unit & $\begin{array}{l}\text { To convert SI to U.S., } \\
\text { multiply by }\end{array}$ \\
\hline 0.3048 & $\mathrm{ft}$ & $\mathrm{m}$ & 3.2808 \\
2.54 & inch $(\mathrm{es})$ & $\mathrm{cm}$ & 0.3937 \\
0.4536 & $\mathrm{lb}$ & $\mathrm{kg}$ & 2.2046 \\
1 & $\mu \mathrm{mho} / \mathrm{cm}$ & $\mu \mathrm{S} \cdot \mathrm{cm}^{-1}$ & 1 \\
28.3495 & $\mathrm{Oz}$ & $\mathrm{g}$ & 0.0353 \\
1 & $\mathrm{ppm}$ & $\mathrm{mg} \cdot \mathrm{kg}^{-1}$ & 1 \\
1 & $\mathrm{ppm}$ & $\mathrm{mg} \cdot \mathrm{L}^{-1}$ & 1 \\
$\left({ }^{\circ} \mathrm{F}-32\right) \div 1.8$ & ${ }^{\circ} \mathrm{F}$ & ${ }^{\circ} \mathrm{C}$ & $\left({ }^{\circ} \mathrm{C} \times 1.8\right)+32$
\end{tabular}


where there is farmer interest in this production system.

Vertical, hydroponic systems require the use of a soilless growing media, but there are many types of media available and each has unique physical and chemical properties. Moreover, media can be mixed in various ratios to achieve multiple benefits. Caso et al. (2009) compared various mixtures of rice husks, pumice, and sand, but the greatest yields were observed in $100 \%$ rice husks. In contrast, other studies have found that a mixture of perlite $(60 \%$ to $80 \%)$ and peat $(20 \%$ to $40 \%)$ maximizes growth and yield of strawberry (Anagnostou and Vasilakakis, 1995; Linardakis and Manios, 1991). While these previous studies demonstrated the value of peat in a soilless mix with perlite, coconut coir may be a sustainable alternative to peat. Peat is harvested from wetland ecosystems, often at unsustainable rates, whereas coconut coir is derived from the mesocarp of coconut fruit (a renewable resource) and has many physical and chemical properties similar to peat (Meerow, 1994).

Many local fruit and vegetable growers are certified organic, and there is increasing interest in organically certified hydroponic systems. In response to this interest, the USDA National Organic Program (NOP) recently appointed a "Hydroponic and Aquaponic Task Force" to assess the compatibility of hydroponic and aquaponic practices with current USDA organic regulations (e-CFR, 2016). Despite consumer demand and farmer interest in organic hydroponic production (Atkin and Nichols, 2004), there has been limited research on the feasibility of using bio-based liquid nutrient solutions currently or potentially allowed under USDA organic regulations to grow vegetables or fruit, including strawberries, in hydroponic culture. Some of the potential challenges of growing organic hydroponic crops include low nitrate to ammonium ratio, alkaline $\mathrm{pH}$, and low dissolved oxygen content of bio-based nutrient solutions (Jewell and Kubota, 2005). Moreover, bio-based nutrients must be mineralized via microbial communities, which can vary greatly among soilless media (Grunert et al., 2016).

Atkin and Nichols (2004) demonstrated the possibility of growing lettuce (Lactuca sativa) with organic nutrient solution in a nutrient film technique hydroponic system, but yield was between two and four times greater in conventional nutrient solution. Given the chemical limitations of organic nutrient solutions, Gül et al. (2007) tested the idea of "charging" soilless media with solid poultry manure to supplement regular fertigation with a solution of dissolved poultry manure. Compared with the inorganic nutrient solution, cucumber (Cucumis sativus) yield was reduced by only $11 \%$ when fertilized with a combination of solid and dissolved poultry manure (Gül et al., 2007). Thus, organic hydroponic production of strawberries may benefit from a combination of liquid and solid nutrient sources.

The objectives of this study were to 1) identify the best cultivars and growing media for vertical, hydroponic, and high tunnel production of strawberries in the midwestern United States and to 2) assess potential strategies for replacing synthetic fertilizer with organic nutrient sources in hydroponic strawberry production.

\section{Materials and methods}

STUDY LOCATIONS AND EXPERIMENTAL SYSTEM. TO accomplish study objectives, a series of three experiments were conducted over the course of 2 years and two locations in Illinois. The first experiment (hereafter, Expt. 1) was conducted in 2012 and 2015 at the Dixon Springs Agricultural Center (DSAC) near Simpson, IL (lat. $37.43^{\circ} \mathrm{N}$, long. $88.67^{\circ} \mathrm{W}$, $164 \mathrm{~m}$ elevation) to assess yields of 11 different strawberry cultivars grown in vertical, hydroponic towers (Verti-Gro, Summerfield, FL) within a high tunnel. The second experiment (hereafter, Expt. 2), also in 2012 and 2015 at DSAC, was conducted to identify an optimum soilless media for strawberries grown in vertical, hydroponic towers. The third experiment (hereafter, Expt. 3) was conducted in 2015 at the Crop Sciences Research and Education Center (CSREC) in Urbana, IL (lat. $40.08^{\circ} \mathrm{N}$, long. $88.20^{\circ} \mathrm{W}, 226 \mathrm{~m}$ elevation) to assess yields of four different strawberry cultivars fertilized with three different nutrient sources in vertical, hydroponic towers within a high tunnel.

Each vertical, hydroponic tower included four square, expanded polystyrene pots stacked in an alternating arrangement around a 5-ft-long (0.75 inch diameter) conduit pipe anchored in the ground. At DSAC (Expts. 1 and 2), towers were placed within a $30 \times 96-\mathrm{ft}$ high tunnel and arranged in twin rows spaced $0.5 \mathrm{~m}$ apart with $1-\mathrm{m}$ spacing between towers within rows. The high tunnel was equipped with electric fans and roll-up sides to improve air circulation. At CSREC (Expt. 3), towers were placed within a $12 \times 85$ - $\mathrm{ft}$ caterpillar tunnel with roll-up sides and arranged in single rows spaced $2 \mathrm{~m}$ apart with $1-\mathrm{m}$ spacing between towers within rows. The roll-up sides for both tunnels remained up unless nighttime air temperatures outside of the tunnel were forecast below $5{ }^{\circ} \mathrm{C}$, and a $50 \%$ shadecloth was installed on the top of both tunnels in late May to help mitigate extreme hot temperatures.

STRAWBERRY MANAGEMENT. In late February or early March of each year, as soon as forecast nighttime air temperatures were consistently above $-6{ }^{\circ} \mathrm{C}$, four plug (2012) or barerooted (2015) strawberry plants were transplanted into soilless media of each pot resulting in a total of 16 plants per tower. Bare-rooted plants were transplanted again in Apr. 2015 at DSAC due to a rare, killing frost in Mar. 2015. Each tower was treated as an individual experimental unit and the number of towers varied by experiment. Strawberries were fertigated one to three times per day, depending on air temperature, light intensity, crop physiological stage, and experimental treatment. Runners were trimmed at least two times per month. Captan (Bonide Products, Oriskany, NY) and Streptomyces lydicus (Actinovate; Natural Industries, Houston, TX) were used to control fungal pathogens and spinosad (Monterey Garden Insect Spray; Lawn and Garden Products, Fresno, CA) was used to control thrips (order Thysanoptera) and spotted wing drosophila (Drosophila suzukii) on fruit.

DSAC CULTIVAR EVALUATION. Expt. 1 in 2012 was a completely randomized design with three replicates of six strawberry cultivars including Albion, Camarosa, Chandler, Monterey, Florida Radiance, and Sweet Charlie. This experiment was repeated in 2015 using a completely randomized design with six replicates of seven strawberry cultivars including Albion, Monterey, Evie 2, Portola, San Andreas, Seascape, and Tribute. Strawberries were planted in a $1: 1$ soilless media mixture (by 
volume) of perlite + coco coir and fertigated with a complete nutrient solution $(6 \mathrm{~N}-5.2 \mathrm{P}-23.2 \mathrm{~K}$; VertiGro Plant Nutrients) supplemented with calcium nitrate. Target electrical conductivity (EC) of the nutrient solution was $1.0 \mu \mathrm{S} \cdot \mathrm{cm}^{-1}$ (Jun et al., 2013 ) and $\mathrm{pH}$ was adjusted to a target of 5.8 with sulfuric acid. Strawberries were harvested from each tower up to four times per week and graded as marketable or cull, separated, and marketable fruit was counted and weighed but cull fruit was not. Harvest occurred between Mar. and July 2012 and between June and Sept. 2015 due to the killing frost and later transplant date.

DSAC MEdia eVAluation. Expt. 2 was a completely randomized design with three (2012) or four (2015) replicates of three possible soilless growing media including, coco coir + perlite ( $1: 1$ by volume), perlite alone, and perlite + vermiculite (1:1 by volume) The strawberry cultivar Monterey was grown in all media in both years. Nutrient source, fertigation, and strawberry harvest and data collection in Expt. 2 was identical to that in Expt. 1.

CSREC CULTIVAR AND NUTRIENT SOURCE EVALUATION. Expt. 3 was a $4 \times 3$ factorial randomized complete block design with five replicates of each factorial combination blocked according to location in the tunnel. The first experimental factor was cultivar and included, Albion, Chandler, San Andreas, and Seascape; the second factor was fertilizer source, which included synthetic (SYN), liquid organic (LO), and liquid organic + vermicompost $(\mathrm{LO}+\mathrm{V})$. In the SYN treatment, plants were fertigated with a complete nutrient solution $(6 \mathrm{~N}-$ 5.2P-23.2K; Verti-Gro Plant Nutrients) and supplemented with calcium nitrate. Target EC of the nutrient solution was $1.0 \mu \mathrm{S} \cdot \mathrm{cm}^{-1}$ and $\mathrm{pH}$ was adjusted to a target of 5.8 with acetic acid. For the first week after transplanting, plants in the SYN treatment were supplemented with chelated calcium (Dyna Gold Calcium 8.25\%; Chemical Dynamics, Plant City, FL), seaweed extract (Organic Seaweed Extract; Maxicrop USA, Elk Grove Village, IL), and magnesium sulfate.

In the $\mathrm{LO}$ and $\mathrm{LO}+\mathrm{V}$ treatments, strawberries were fertigated five times per week with a bio-based nutrient solution (6N-0P-13.3K; Organic Plant Food Solution, Verti-Gro), two times per week with fermented molasses (Verti-Gro), two times per month with a bio-based trace mineral solution (Organic Trace Mineral Solution, Verti-Gro), and each pot received a weekly hand-application of fish emulsion fertilizer $(5 \mathrm{~N}-0.4 \mathrm{P}-0.8 \mathrm{~K}$; Ferti-Lome, Bonham, TX). Solution $\mathrm{pH}$ was not adjusted in the $\mathrm{LO}$ and $\mathrm{LO}+\mathrm{V}$ treatments due to the volatility of $\mathrm{pH}$ in bio-based nutrient solution (Jewell and Kubota, 2005) and the absence of a potentially allowable and effective acid input in organic hydroponic production. The soilless media for the SYN and LO treatments consisted of a 1:1 media mixture (by volume) of perlite + coco coir, and the $\mathrm{LO}+\mathrm{V}$ soilless media included $10 \%$ vermicompost by volume resulting in a 4.5:4.5:1 mix of perlite + coco coir + vermicompost. Chemical analysis of the vermicompost and nutrient solutions used in Expt. 3 are reported in Table 1 .

Air temperature was measured $5 \mathrm{ft}$ from ground surface and logged every $30 \mathrm{~min}$ (HOBO Pro V2; Onset Computer, Bourne, MA) between 9 Mar. and 8 Aug. 2015 within the center of the tunnel at CSREC. The $\mathrm{pH}$ and EC of nutrient solution entering the towers (collected from emitters above towers) and effluent leaving the towers (collected from the bottom of the fourth pot in the tower) were measured two times per month across all fertilizer treatments, but only within the Albion cultivar treatment across three replicate blocks. At each sampling interval, $50 \mathrm{~mL}$ of nutrient solution or effluent was collected and $\mathrm{pH}$ and $\mathrm{EC}$ were determined using an $\mathrm{EC} / \mathrm{pH}$ pen (Hanna Instruments, Woonsocket, RI). Leaf greenness, a reliable proxy for leaf chlorophyll (Zhu et al., 2012), was recorded monthly with an atLEAF+ meter (FT Green, Wilmington, DE). Greenness was measured near the middle of the newest fully emerged leaf from one plant per tower level in all factorial treatment combinations. Strawberries were harvested in May and June 2015 from each tower up to four times per week and graded as marketable or cull, separated, and both marketable and cull fruit were counted and weighed.

Data analysis. All data were analyzed with analysis of variance [Proc Mixed (SAS version 9.3; SAS Institute, Cary, NC)]. The fixed treatment effect was cultivar in Expt. 1 and growing media in Expt. 2 (without any random effects because of the completely randomized experimental design). In Expt. 3, fixed effects in the mixed model for yield response included cultivar, fertilizer source, and their interaction, and the random effect was replicate block. Repeated measures analysis was used for measures of leaf greenness and solution/effluent $\mathrm{pH}$ and EC. For the leaf greenness response, fixed effects included cultivar, fertilizer source, tower level, sampling date, and all possible interactions. Sampling date was treated as a repeated effect and replicate block was the random effect. For solution and effluent $\mathrm{pH}$ and EC response, fixed effects included fertilizer source, sampling date, and their interaction. Similar to leaf greenness, sampling date was a repeated effect and replicate block was the random effect. All data were tested for assumptions of analysis of variance using Proc Univariate (SAS version 9.3), and differences among least squares means were determined using the Tukey-Kramer multiple comparisons test at a significance level of $\alpha=0.05$.

\section{Results and discussion}

DSAC CULTIVAR EVALUATION (EXPT. 1). Cultivar influenced strawberry weight per tower [yield $(P<$ $0.0001)]$ and per berry $(P<0.0001)$, and number per tower $(P<0.0001)$ in 2012 and 2015 at DSAC. 'Florida Radiance' and 'Monterey' produced the greatest yields (lb/tower) in 2012, while 'Evie 2' and 'Portola' were the top-yielding cultivars in 2015 (Table 2). Of the seven cultivars tested in 2015, yield from Monterey was 35\% less than Evie 2. 'Camarosa' produced the most berries in 2012, but those berries were relatively small. In contrast, 'Florida Radiance' produced fewer berries, but the berries were the largest among the six cultivars tested in 2012. 'Portola' was high yielding and produced the largest berries in 2015. 'Evie 2' produced the most berries per tower of the cultivars tested in 2015, which contributed to the greatest yield per tower despite medium-sized berries. Consistent with the results of this study, Rowley et al. (2011) found that 'Evie 2 ' was a consistently high-yielding strawberry cultivar with acceptable berry size in high tunnel production. Similarly, 'Florida Radiance' has been a top-yielding strawberry cultivar in Florida field production systems (Santos et al., 2009). Results of this 
Table 1. Chemical analysis of well water, synthetic and organic nutrient solutions, and vermicompost used for experimental treatments at the Crop Sciences Research and Education Center in Urbana, IL, in 2015. Samples were analyzed 15 Apr. 2015 and values reported are means of two replicate samples.

\begin{tabular}{|c|c|c|c|c|c|c|c|}
\hline & \multirow[b]{2}{*}{ Well } & \multirow{2}{*}{$\frac{S \mathrm{~N}^{\mathrm{z}}}{6 \mathrm{~N}-5.2 \mathrm{P}-23.2 \mathrm{~K}}$} & \multicolumn{4}{|c|}{$\mathrm{LO}^{\mathbf{z}}$} & \multirow{2}{*}{$\frac{\mathrm{LO}+\mathrm{V}^{\mathrm{z}}}{\text { Vermicompost }}$} \\
\hline & & & $6 \mathrm{~N}-0 \mathrm{P}-13.3 \mathrm{~K}$ & Molasses & Trace & Fish emulsion & \\
\hline $\mathrm{pH}$ & 8.7 & 5.8 & 7.3 & 7.3 & 8.0 & 4.7 & 6.7 \\
\hline & \multicolumn{6}{|c|}{$\mathrm{mg} \cdot \mathrm{L}^{-1}(\mathrm{ppm})$} & $\mathrm{mg} \cdot \mathrm{kg}^{-1}(\mathrm{ppm})$ \\
\hline Nitrate & 1 & 150 & 42 & 20 & 11 & 671 & 1,345 \\
\hline Ammonium & 0 & 6 & 3 & 3 & 2 & 24 & - \\
\hline Potassium & 2 & 225 & 171 & 27 & 7 & 230 & 4,105 \\
\hline Sulfate & 0 & 40 & 119 & 2 & 2 & 281 & 288 \\
\hline Calcium & 13 & 104 & 22 & 18 & 20 & 327 & 4,608 \\
\hline Magnesium & 15 & 51 & 59 & 16 & 15 & 28 & 909 \\
\hline Boron & 0.39 & 0.78 & 0.43 & 0.54 & 0.47 & 0.37 & - \\
\hline Iron & 0.01 & 4.0 & 0.2 & 0.7 & 0.3 & 2.0 & 15.4 \\
\hline
\end{tabular}

${ }^{z} \mathrm{SYN}=$ synthetic fertilizer; $\mathrm{LO}=$ liquid organic $; \mathrm{LO}+\mathrm{V}=\mathrm{LO}+$ vermicompost.

${ }^{\mathrm{E}} \mathrm{EC} ; 1 \mu \mathrm{S} \cdot \mathrm{cm}^{-1}=1 \mu \mathrm{mho} / \mathrm{cm}$.

Table 2. Means of marketable strawberry yield (weight per tower, number per tower, and weight per berry) of 11 different cultivars in 2012 and/or 2015 at the Dixon Springs Agricultural Center near Simpson, IL.

\begin{tabular}{|c|c|c|c|c|c|c|}
\hline \multirow[b]{3}{*}{ Cultivar } & \multicolumn{6}{|c|}{ Strawberry yield } \\
\hline & \multicolumn{3}{|c|}{2012} & \multicolumn{3}{|c|}{2015} \\
\hline & lb/tower & Berries/tower & oz/berry ${ }^{z}$ & $\mathrm{lb} /$ tower & Berries/tower & $\overline{\text { oz/berry }}$ \\
\hline Camarosa & $13.4 \mathrm{bc}$ & $437 \mathrm{a}$ & $0.49 \mathrm{bc}$ & - & - & - \\
\hline Chandler & $12.7 \mathrm{bc}$ & $356 \mathrm{bc}$ & $0.58 \mathrm{~b}$ & - & - & - \\
\hline Monterey & $14.5 \mathrm{ab}$ & $392 \mathrm{ab}$ & $0.59 \mathrm{~b}$ & $10.3 \mathrm{~cd}$ & $410 \mathrm{bc}$ & $0.40 \mathrm{~cd}$ \\
\hline Evie 2 & - & - & - & $15.8 \mathrm{a}$ & $629 \mathrm{a}$ & $0.40 \mathrm{~cd}$ \\
\hline Portola & - & - & - & $13.6 \mathrm{ab}$ & $420 \mathrm{bc}$ & $0.52 \mathrm{a}$ \\
\hline San Andreas & - & - & - & $10.2 \mathrm{~cd}$ & $334 \mathrm{c}$ & $0.49 \mathrm{ab}$ \\
\hline Seascape & - & - & - & $9.7 \mathrm{~cd}$ & $422 \mathrm{bc}$ & $0.37 \mathrm{~d}$ \\
\hline Tribute & - & - & - & $7.8 \mathrm{~d}$ & $501 \mathrm{~b}$ & $0.25 \mathrm{e}$ \\
\hline
\end{tabular}

${ }^{\mathrm{z}} 1 \mathrm{lb}=0.4536 \mathrm{~kg} ; \mathrm{loz}=28.3495 \mathrm{~g}$.

y Different letters within a column indicate differences at a significance level of $\alpha=0.05$ using the Tukey-Kramer multiple comparison test.

cultivar evaluation are difficult to compare with others in the literature given the stark differences in climate and production systems used among studies. Nonetheless, the limited evidence from this study and others suggests that 'Florida Radiance' and 'Evie 2' may have high yield potential across more than one production system and climate. However, these cultivars were tested in only 1 year of this study and further replication will be needed to confirm their suitability for hydroponic, high tunnel production in the midwestern United States.

DSAC MEDia EVALUATION (ЕхРт. 2). Growing media influenced strawberry (cv. Monterey) weight per tower [yield $(P=0.01)$ ] and per berry $(P=0.006)$, but not number per tower $(P=0.12)$ in 2012. Mixtures of media (coco coir or vermiculite mixed with perlite) resulted in greater strawberry yield and weight per berry than perlite alone (Table 3). Trends were similar in 2015 , but there were no significant differences among growing media tested. Nonetheless, first year results are consistent with previous studies demonstrating the benefits of soilless media mixtures relative to perlite alone for hydroponic strawberry production in vertical towers (Anagnostou and Vasilakakis, 1995; Linardakis and Manios, 1991).
Moreover, results confirm that coco coir can contribute to a productive, and potentially more sustainable, soilless media mix (Meerow, 1994).

CSREC CULTIVAR AND NUTRIENT SOURCE EVALUATION (ЕхРт. 3). Similar to results at DSAC, cultivar influenced marketable strawberry weight per tower $(P<0.0001)$ and per berry $(P<0.0001)$, and number per tower $(P<0.0001)$ at CSREC. Seascape was the top-yielding cultivar, producing the greatest weight and number of berries per tower, but individual berries were of medium size (Table 4). 'Albion' was the second most productive cultivar 
at CSREC, but it produced the largest individual berries. Rowley et al. (2011) found that 'Seascape' (along with 'Evie 2') was a high-yielding cultivar in the high tunnel environment; however, 'Albion' was the lowest-yielding cultivar of the four they tested. In contrast, Burlakoti et al. (2013) found that high tunnel yield of 'Albion' in Canada was equal to (2009) or two times greater than (2010) yield of 'Seascape'. Variability of yield results emphasizes the importance of genotype by environment interactions and the need for location-specific cultivar evaluations, especially given the sustained growth of local food demand and specialty crop production in new areas of the United States (Feldmann and Hamm, 2015).

Table 3. Means of marketable strawberry yield (weight per tower, number per tower, and weight per berry) of the Monterey cultivar grown in three different soilless media in 2012 and 2015 at the Dixon Springs Agricultural Center near Simpson, IL.

\begin{tabular}{|c|c|c|c|}
\hline \multirow[b]{2}{*}{ Media } & \multicolumn{3}{|c|}{ Strawberry yield } \\
\hline & $\mathrm{lb} /$ tower $^{\mathrm{z}}$ & Berries/tower & oz/berry \\
\hline \multicolumn{4}{|l|}{2012} \\
\hline Coco coir/perlite & $16.3 \mathrm{a}^{\mathrm{y}}$ & $432 \mathrm{a}$ & $0.60 \mathrm{a}$ \\
\hline Perlite & $12.4 \mathrm{~b}$ & $367 \mathrm{a}$ & $0.54 \mathrm{~b}$ \\
\hline Perlite/vermiculite & $14.5 \mathrm{ab}$ & $392 \mathrm{a}$ & $0.59 \mathrm{a}$ \\
\hline SE & 0.6 & 19 & 0.01 \\
\hline \multicolumn{4}{|l|}{2015} \\
\hline Coco coir/perlite & $12.7 \mathrm{a}$ & $493 \mathrm{a}$ & $0.41 \mathrm{a}$ \\
\hline Perlite & $11.2 \mathrm{a}$ & $450 \mathrm{a}$ & $0.40 \mathrm{a}$ \\
\hline Perlite/vermiculite & $12.4 \mathrm{a}$ & $484 \mathrm{a}$ & $0.41 \mathrm{a}$ \\
\hline SE & 1.0 & 34 & 0.01 \\
\hline
\end{tabular}

There was no interaction between cultivar and nutrient source for any measures of yield, but strawberry weight per tower was influenced by nutrient source $(P=0.01)$. Pooled across all cultivars, strawberry weight per tower was greatest when fertilized with the synthetic nutrient solution (SYN) and lowest when fertilized with the $\mathrm{LO}+\mathrm{V}$ nutrient source (Table 4 ). Yield loss in the $\mathrm{LO}+\mathrm{V}$ treatment relative to SYN was $15 \%$, which is similar to that reported for organic hydroponic cucumber (Gül et al., 2007) and far less than yield loss reported for organic hydroponic lettuce (Atkin and Nichols, 2004). Combined, these results suggest that fruiting crops may be better candidates for organic hydroponic production than leafy

Table 4. Marketable and cull strawberry yield (weight per tower, number per tower, and weight per berry) for four cultivars and three fertilizer strategies in the 2015 trial at the Crop Sciences Research and Education Center in Urbana, IL.

\begin{tabular}{|c|c|c|c|c|c|c|}
\hline \multirow[b]{3}{*}{ Treatment } & \multicolumn{6}{|c|}{ Strawberry yield } \\
\hline & \multicolumn{3}{|c|}{ Marketable } & \multicolumn{3}{|c|}{ Cull } \\
\hline & $\mathrm{lb} /$ tower $^{\mathrm{z}}$ & Berries/tower & oz/berry ${ }^{z}$ & lb/tower & Berries/tower & oz/berry \\
\hline Albion & $5.7 \mathrm{~b}^{y}$ & $176 \mathrm{~b}$ & $0.53 \mathrm{a}$ & $0.8 \mathrm{bc}$ & $52 \mathrm{bc}$ & $0.29 \mathrm{a}$ \\
\hline Chandler & $3.1 \mathrm{c}$ & $121 \mathrm{c}$ & $0.40 \mathrm{c}$ & $0.5 \mathrm{c}$ & $33 \mathrm{c}$ & $0.24 \mathrm{a}$ \\
\hline San Andreas & $3.8 \mathrm{c}$ & $123 c$ & $0.51 \mathrm{ab}$ & $1.0 \mathrm{~b}$ & $71 \mathrm{ab}$ & $0.26 \mathrm{a}$ \\
\hline \multicolumn{7}{|l|}{ Fertilizer $^{x}$} \\
\hline SYN & $5.2 \mathrm{a}$ & $171 \mathrm{a}$ & $0.50 \mathrm{a}$ & $1.2 \mathrm{a}$ & $79 \mathrm{a}$ & $0.28 \mathrm{a}$ \\
\hline $\mathrm{LO}$ & $4.7 \mathrm{ab}$ & $165 \mathrm{a}$ & $0.46 \mathrm{a}$ & $0.8 \mathrm{~b}$ & $65 \mathrm{ab}$ & $0.24 \mathrm{a}$ \\
\hline $\mathrm{LO}+\mathrm{V}$ & $4.4 \mathrm{~b}$ & $153 \mathrm{a}$ & $0.47 \mathrm{a}$ & $0.9 \mathrm{~b}$ & $5 \mathrm{lb}$ & $0.27 \mathrm{a}$ \\
\hline SE & 0.3 & 8 & 0.02 & 0.1 & 11 & 0.02 \\
\hline
\end{tabular}

${ }^{2} \mathrm{l} \mathrm{lb}=0.4536 \mathrm{~kg} ; \mathrm{l} \mathrm{oz}=28.3495 \mathrm{~g}$.

${ }^{y}$ Different letters within a column and treatment level (cultivar or fertilizer) indicate differences at a significance level of $\alpha=0.05$ using the Tukey-Kramer multiple comparison test.

${ }^{\mathrm{x}} \mathrm{SYN}=$ synthetic fertilizer; $\mathrm{LO}=$ liquid organic; $\mathrm{LO}+\mathrm{V}=\mathrm{LO}+$ vermicompost. 
tunnels, and volatility of air temperature tends to increase as air volume decreases in polyethylene tunnels (Lamont, 2005). Thus, it is possible that the caterpillar tunnel at CSREC was insufficient for protecting strawberries from cool temperatures early in the growing season and extreme hot temperatures in the middle of the growing season. Extended exposure to daytime temperatures between 30 and $40{ }^{\circ} \mathrm{C}$ is detrimental to photosynthesis, floral development, fruit set, and yield in strawberry (Kadir et al., 2006). Air temperatures in the caterpillar tunnel at CSREC reached $42{ }^{\circ} \mathrm{C}$ on $13 \mathrm{Apr}$. $2015,40{ }^{\circ} \mathrm{C}$ on 25 May 2015, and regularly reached levels above $30^{\circ} \mathrm{C}$ for much of June and July (Fig. 1). Warmer temperatures and crop physiological stress in the tunnel at CSREC also limited the length of the marketable harvest period to two months, whereas berries were harvested for four months in both years at DSAC. Unfortunately, we do not have air temperature data from within the high tunnel at DSAC to elucidate site differences.

VERTICAL TOWER DYNAMICS. EC of tower effluent (leaving the bottom of tower level four) was influenced by the interaction of nutrient source and time $(P<0.0001)$ and generally increased over time until towers were flushed with water on 27 June 2015 to remediate potential salt damage (Table 5). Salt buildup can occur after long-term or repeated use of soilless media including perlite (Asaduzzaman et al., 2013), and effluent should be carefully monitored to avoid physiological stress and yield loss. Fertigation events should provide enough solution to allow for leaching and removal of excess salts (Shaw et al., 2004). However, if EC of effluent continues to increase, a leaching event with water alone can at least temporarily alleviate the problem (Table 5 ).

Leaf greenness was influenced by the three-way interaction of nutrient

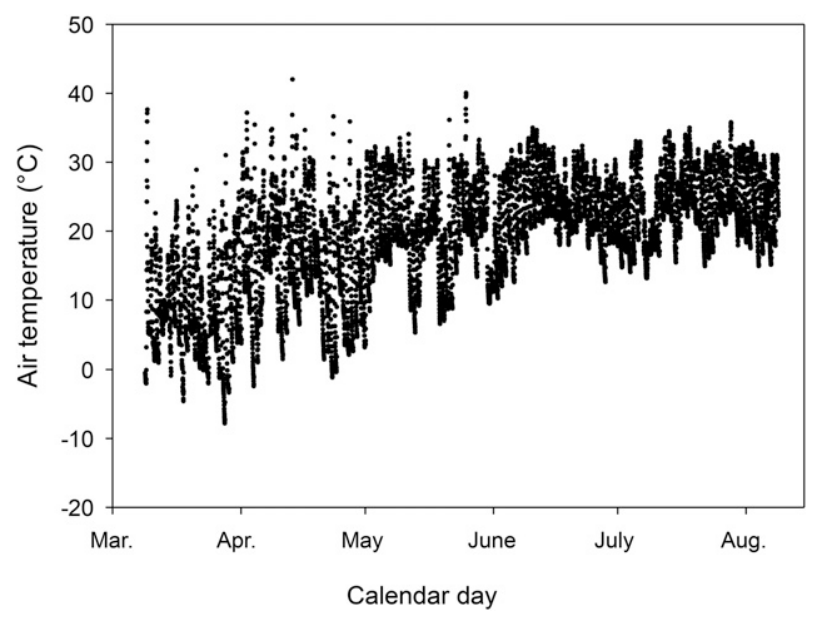

Fig. 1. Air temperatures recorded between 9 Mar. and 8 Aug. 2015 every 30 min from the center of the caterpillar tunnel, $5 \mathrm{ft}(1.5 \mathrm{~m})$ from ground surface at the Crop Sciences Research and Education Center in Urbana, IL; $\left(1.8 \times{ }^{\circ} \mathrm{C}\right)+32={ }^{\circ} \mathrm{F}$.

Table 5. Electrical conductivity (EC) of solution entering tower level 1 and effluent leaving level 4 between Apr. and July across three fertilizer treatments at the Crop Sciences Research and Education Center in Urbana, IL, in 2015.

\begin{tabular}{|c|c|c|c|c|c|c|}
\hline \multirow[b]{2}{*}{ Date } & \multicolumn{3}{|c|}{ Solution EC $\left(\mu S \cdot \mathrm{cm}^{-1}\right)^{\mathrm{z}}$} & \multicolumn{3}{|c|}{ Effluent EC $\left(\mu S \cdot \mathrm{cm}^{-1}\right)$} \\
\hline & SYN $^{y}$ & $\mathrm{LO}^{\mathrm{y}}$ & $\mathrm{LO}+\mathrm{V}^{\mathrm{y}}$ & SYN & LO & $\mathrm{LO}+\mathrm{V}$ \\
\hline 24 Apr. & 1.10 & 0.49 & 0.44 & 0.77 & 0.58 & 0.73 \\
\hline 19 May & 1.67 & 1.15 & 1.16 & 1.69 & 1.15 & 1.39 \\
\hline l June & 1.55 & 0.94 & 0.94 & 1.52 & 1.18 & 1.32 \\
\hline 16 June & 1.25 & 0.78 & 1.01 & 1.39 & 1.38 & 1.73 \\
\hline 28 July & 1.50 & 0.77 & 1.00 & 1.89 & 1.34 & 1.51 \\
\hline SE & 0.15 & 0.15 & 0.15 & 0.13 & 0.13 & 0.13 \\
\hline
\end{tabular}

${ }^{\mathrm{z}} \mathrm{EC} ; \mathrm{l} \mu \mathrm{S} \cdot \mathrm{cm}^{-1}=1 \mu \mathrm{mho} / \mathrm{cm}$

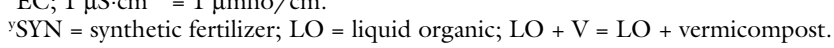

Table 6. atLEAF + values, a measure of leaf greenness and proxy for leaf chlorophyll, measured between Apr. and June, in each tower, and across three fertilizer treatments at the Crop Sciences Research and Education Center in Urbana, IL, in 2015. Data are pooled across all cultivars due to a lack of interactions. se for least squares means $=1.37$.

\begin{tabular}{|c|c|c|c|c|c|c|c|c|c|c|c|c|}
\hline \multirow[b]{3}{*}{ Tower level } & \multicolumn{12}{|c|}{ atLEAF + value (relative leaf greenness) } \\
\hline & \multicolumn{4}{|c|}{$\mathrm{SYN}^{\mathrm{z}}$} & \multicolumn{4}{|c|}{$\mathbf{L O}^{\mathbf{z}}$} & \multicolumn{4}{|c|}{$\mathrm{LO}+\mathrm{V}^{\mathrm{z}}$} \\
\hline & 9 Apr. & 28 Apr. & 26 May & 23 June & 9 Apr. & 28 Apr. & 26 May & 23 June & 9 Apr. & 28 Apr. & 26 May & 23 June \\
\hline Level 2 & 45.9 & 48.3 & 41.0 & 41.5 & 45.6 & 47.2 & 48.6 & 49.4 & 42.5 & 43.4 & 39.1 & 42.6 \\
\hline Level 3 & 47.8 & 49.0 & 38.7 & 39.5 & 42.8 & 47.2 & 50.6 & 49.9 & 44.5 & 40.3 & 38.5 & 40.2 \\
\hline Level 4 & 46.6 & 48.7 & 45.0 & 47.9 & 42.6 & 45.2 & 50.1 & 51.0 & 42.9 & 41.5 & 34.9 & 40.9 \\
\hline
\end{tabular}

${ }^{\mathrm{z}} \mathrm{SYN}=$ Synthetic fertilizer; $\mathrm{LO}=$ liquid organic; $\mathrm{LO}+\mathrm{V}=\mathrm{LO}+$ vermicompost. 
source $\times$ tower level $\times$ time $(P=$ $0.0004)$. Greenness of leaves in tower levels two and three of the SYN treatment decreased over time, while leaf greenness in levels one and four was consistent throughout the experiment (Table 6). In the LO treatment, leaf greenness was greatest in tower levels one and two in April, but by May plants in levels three and four were greener than those near the top of the tower. Crop yield in vertical production systems is typically reduced in the lower tower levels (Takeda et al., 1997), presumably due to light interference and reduced chlorophyll content (on a leaf area basis) of shaded plants near the bottom of the tower (Cooper and Qualls, 1967). Although shading may have initially reduced chlorophyll content, increased leaf greenness in lower levels over time may be due to the accumulation of nitrate in the soilless media, as evidenced by increasing EC of effluent leaching from the bottom of tower level four over time (Table 5 ). Leaf greenness and tissue nitrogen content are well correlated in many crop species, but this relationship is much weaker in strawberry leaves (Wood et al., 1993). Plants in the $\mathrm{LO}+\mathrm{V}$ treatment followed a more predictable trend, where leaf greenness decreased from the top to the bottom of the tower and the effect became more pronounced with time. The EC of effluent leaving towers in the $\mathrm{LO}+\mathrm{V}$ treatment was greater than that in the LO treatment, which suggests nutrient availability was not responsible for changes in leaf greenness among tower level. Further research is needed to understand strawberry (and other crops) physiological response to position within vertical, hydroponic towers.

\section{Conclusions}

Results of these experiments suggest that strawberries should be planted in perlite mixed with coco coir or vermiculite and fertilized with synthetic fertilizer to maximize yield in vertical, hydroponic, high tunnel systems of the midwestern United States. Strawberry yield among cultivars varied by year and location, but Florida Radiance, Monterey, Evie 2, Portola, and Seascape were among the highest-yielding cultivars in at least one site-year. Yield variability emphasizes the need for locationspecific cultivar testing over multiple years, but results also suggest that cultivar recommendations from conventional hydroponic systems can likely be used to inform organic hydroponic production. Based on nutrient source alone, certified organic hydroponic production seems feasible; observed yield loss (15\%) was similar to what has been reported for well-managed organic systems (13\%) compared with conventional systems (Seufert et al., 2012). However, strawberries in this study were not managed strictly according to USDA NOP guidelines. Indeed, yield loss in the organic nutrient treatments may have been more severe in the absence of synthetic pesticide use at CSREC (captan is a prohibited input under NOP guidelines).

Economic feasibility of this production system will depend on a number of variable and fixed costs and existing infrastructure on an individual farm including, high tunnels, hydroponic supplies (e.g., fertilizer injectors, drip irrigation supplies, soilless media, and polystyrene pots), strawberry plants, crop inputs (e.g., fertilizer and pesticides), labor, management system (e.g., conventional or organic), marketing strategies (e.g., wholesale, direct market, or "U-Pick"), and the fate of cull fruit (e.g., processing for value-added farm-stand products). A comparison of these different economic scenarios was beyond the scope of this study, but crop consultants and extension educators can use yield per tower estimates and local, seasonal market value for strawberries as a starting point to inform individual grower decisions about the feasibility of vertical, hydroponic, high tunnel production of strawberries in the midwestern United States. However, it is important to note that hydroponic systems and high tunnels require significant capital investment (relative to open field, soil-based production), and growers should carefully consider their potential return on investment before adoption. As an example, a typical $30 \times 96-\mathrm{ft}$ high tunnel currently costs $>\$ 7000$ and a vertical hydroponic system to fill that space costs $>\$ 6500$. This total initial investment $(>\$ 13,500)$, and the depreciation of the equipment over time, are potentially significant barriers to the adoption of this system; thus, future studies should focus on critically assessing economic feasibility and possible management scenarios for improving profitability and return on investment.

\section{Literature cited}

Anagnostou, K. and M.D. Vasilakakis. 1995. Effect of substrate and cultivar on earliness, plant productivity, and fruit quality of strawberry. Acta Hort. 379:267274.

Asaduzzaman, M., Y. Kobayashi, M.F. Mondal, T. Ban, H. Matsubara, F. Adachi, and T. Asao. 2013. Growing carrots hydroponically using perlite substrates. Sci. Hort. 159:113-121.

Atkin, K. and M.A. Nichols. 2004. Organic hydroponics. Acta Hort. 648:121127.

Burlakoti, R.R., J. Zandstra, and K. Jackson. 2013. Comparison of epidemiology of gray mold, anthracnose fruit rot, and powdery mildew in day-neutral strawberries in field and high-tunnel conditions in Ontario. Intl. J. Fruit Sci. 13:19-27.

Caso, C., M. Chang, and A. RodríguezDelfín. 2009. Effect of the growing media on the strawberry production in column system. Acta Hort. 843:373-380.

Cooper, C.S. and M. Qualls. 1967. Morphology and chlorophyll content of shade and sun leaves of two legumes. Crop Sci. 7:672-673.

Electronic Code of Federal Regulations (e-CFR). 2016. Part 205-National Organic Program. 1 June 2016. <http:// www.ecfr.gov/cgi-bin/text-idx?c=ecfr \& sid $=3$ f34f4c22f9aa8e6d9864cc2683cea02\& tpl=/ecfrbrowse/Title07/7cfr205_main_ 02.tpl>.

Feldmann, C. and U. Hamm. 2015. Consumers' perceptions and preferences for local food: A review. Food Quality Preference 40(part A):152-164.

Grunert, O., E. Hernandez-Sanabria, R. Vilchez-Vargas, R. Jauregui, D.H. Pieper, M. Perneel, M.-C. Van Labeke, D. Reheul, and N. Boon. 2016. Mineral and organic growing media have distinct community structure, stability and functionality in soilless culture systems. Scientific Rpt. 6:18837.

Gül, A., F. Kıdoğlu, and D. Anaç. 2007. Effect of nutrient sources on cucumber production in different substrates. Sci. Hort. 113:216-220.

Jewell, B. and C. Kubota. 2005. Challenges of organic hydroponic production 
of strawberries (Fragaria $\times$ ananassa). HortScience 40:1010-1011 (abstr.).

Jun, H.J., M.S. Byun, S.S. Liu, E.H. Jeon, and Y.B. Lee. 2013. Effect of nutrient solution strength on growth, fruit quality and yield of strawberry "Maehyang" in hydroponics. Korean J. Hort. Sci. Technol. 31:173-178.

Kadir, S., G. Sidhu, and K. Al-Khatib. 2006. Strawberry (Fragaria $\times$ ananassa Duch.) growth and productivity as affected by temperature. HortScience 41: 1423-1430.

Karakoudas, N.G., O.S. Wells, J.B. Loy, and W.G. Lord. 1998. An environmentally modified, vertical growing system for intensive strawberry crop production. HortScience 33:207 (abstr.).

Knewtson, S.J.B., E.E. Carey, and M.B. Kirkham. 2010. Management practices of growers using high tunnels in the central Great Plains of the United States. HortTechnology 20:639-645.

LaMondia, J.A., W.H. Elmer, T.L. Mervosh, and R.S. Cowles. 2002. Integrated management of strawberry pests by rotation and intercropping. Crop Prot. 21:837-846.

Lamont, W.J. 2005. Plastics: Modifying the microclimate for the production of vegetable crops. HortTechnology 15:477481 .

Linardakis, D.K. and V.I. Manios. 1991. Hydroponic culture of strawberries in plastic greenhouse in a vertical system. Acta Hort. 287:317-326.

Meerow, A.W. 1994. Growth of two subtropical ornamentals using coir ( $\mathrm{CO}^{-}$ conut mesocarp pith) as a peat substitute. HortScience 29:1484-1486.

Miranda, F.R. de, V.B. da Silva, F.S.R. dos Santos, A.G. Rossetti, and C. de F.B. da Silva. 2014. Production of strawberry cultivars in closed hydroponic systems and coconut fibre substrate. Revista Ciência Agronômica 45:833-841.

Renaud, E.N.C., E.T.L. van Bueren, J.R. Myers, M.J. Paulo, F.A. van Eeuwijk, N. Zhu, and J.A. Juvik. 2014. Variation in broccoli cultivar phytochemical content under organic and conventional management systems: Implications in breeding for nutrition. PLoS One 9:e95683.

Rowley, D., B.L. Black, D. Drost, and D. Feuz. 2011. Late-season strawberry production using day-neutral cultivars in high-elevation high tunnels. HortScience 46:1480-1485.

Santos, B.M., C.K. Chandler, M. Ramírez-Sánchez, and T.P. Salamé. 2009. Evaluation of strawberry cultivars in Florida. Intl. J. Fruit Sci. 9:419-424.

Seufert, V., N. Ramankutty, and J.A. Foley. 2012. Comparing the yields of organic and conventional agriculture. Nature 485:229-232.

Shaw, N.L., D.J. Cantliffe, J. Funes, and C. Shine. 2004. Successful beit alpha cucumber production in the greenhouse using pine bark as an alternative soilless media. HortTechnology 14:289-294.

Takeda, F., P.R. Adler, and D.M. Glenn. 1997. Strawberry production linked to aquaculture wastewater treatment. Acta Hort. 439:673-678.

U.S. Department of Agriculture. 2012. Bananas and apples remain America's favorite fresh fruits. 13 Apr. 2016. <http:// www.ers.usda.gov/data-products/chartgallery/detail.aspx? chartId=30486 $>$.

Wien, H.C. 2009. Microenvironmental variations within the high tunnel. HortScience 44:235-238.

Wood, C.W., D.W. Reeves, and D.G. Himelrick. 1993. Relationships between chlorophyll meter readings and leaf chlorophyll concentration, $\mathrm{N}$ status, and crop yield: A review. Proc. Agron. Soc. N.Z. 23:1-9.

Wortman, S.E., C.A. Francis, T.D. Galusha, C. Hoagland, J.V. Wart, P.S. Baenziger, T. Hoegemeyer, and M. Johnson. 2013. Evaluating cultivars for organic farming: Maize, soybean, and wheat genotype by system interactions in eastern Nebraska. Agroecol. Sustainable Food Systems 37:915-932.

Wortman, S.E. 2015. Crop physiological response to nutrient solution electrical conductivity and $\mathrm{pH}$ in an ebb-and-flow hydroponic system. Sci. Hort. 194:34-42.

Zhu, J., N. Tremblay, and Y. Liang. 2012. Comparing SPAD and atLEAF values for chlorophyll assessment in crop species. Can. J. Soil Sci. 92:645-648. 